\title{
Copanlisib Regimen
}

National Cancer Institute

\section{Source}

National Cancer Institute. Copanlisib Regimen. NCI Thesaurus. Code C160799.

A regimen consisting of copanlisib hydrochloride that may be used in the treatment of relapsed follicular lymphoma. 